finding their way back to their homes after having been conveyed from them in such a way as to preclude the possibility of their seeing the road by which they travelled, contains, I think, the solution of a hitherto perplexing problem. To ascribe this power, as is usual, to instinct in the customary sense of the term, is to give what $\mathrm{Mr}$. Bain calls " an illusory explanation of repeating the fact in different language," and it is manifestly impossible to ascribe it to instinct, as that term is understood in the evolution theory of mind. I am glad to see a psychologist like Prof. Robertson giving in his adhesion to Mr. Wallace's view. But while in the main accepting it, and arguing forcibly in its favour, Prof Robertson hesitates to affirm that it affords an explanation of the whole of the facts in question. Is this failure, if failure there be, inherent in the explanation itself, or does it lie in our imperfect knowledge of the facts to be explained? That there are difficulties cannot be denied. For example, it is difficult, to say the least, for the human mind to form the conception of a sense of smell, so acute, so objective, and furnishing sensations so strongly persistent in the ideal, as to enable an animal by its means alone, to retrace unerringly long and devious roads travelled over but once, and under circumstances rendering impossible the co-ordination of sights and smells habitual to the animal. In such cases smell must be a much closer second, if second at all, to sight, than touch is in man. No blindfolded man could nerform a like feat by means of unaided touch, nor, do I think, could a blind man, though with the blind this sense becomes, by the cultivation it receives through a hard necessity, greatly more acute than it is in normal cases. But difficulties like these are such, I believe, only because of our very limited acquaintance with the psychology of the lower animals. One of the chief desiderata in mental science is, it seems to me, such a psychology, based upon principles generalised according to strict inductive methods, from a body of numerous, varied, wellauthenticated, and scientifically made observations of the domestic and other animals. A work of this kind we have not, but, I believe, the lines upon which it should be constructed are already laid down in Mr. Spencer's truly great work, the "Principles of Psychology." When this branch of psychological science has been brought into something like parallelism with human psychology, difficulties, such as I have hinted at, will, I venture to say, be effectually removed, and Mr. Wallace's explanation will, as he claims for it, "cover all the well-authenticated cases of this kind."

In the extended scope claimed for this hypothesis by Prof. Robertson, viz, as explanatory of the nature of external perception in dogs, there appears to be a difficulty raised. The most refined and deep-penetrating psychological analysis, of both the empiristic and evolution schools, have incontestably estab. lished that our mature visual presentations are but symbols of the earlier and really genetic presentations acquired through touch combined with masculas feeling. Granting, as seems undeniable, that smell in dogs holds, in many respects, a place analogous to that of touch in man, would the earliest and the genetic presentations of externality in these animals be those furnished by smell, with or without the aid of muscular feeling?

Before concluding my letter, I should like to offer a remark upon the supposed experimentum crucis of Mr. Wallace's hypothesis, suggested by rifr. Bennett. The smell of stale fish would undoubtedly interfere with and overpower ordinary smells in the human organ. Bat is it not an anthropomorphical fallacy to assume, as Mr. Bennett appears to do, that such would be the result in the case of a cat? From the almost purely subjective and comparatively undeveloped sense of smell possessed by man, there appears to me to be no conclusive argument to the highly objective and extremely acute sense of smell possessed by certain animals. We are not warranted from our own experience in inferring of a sense, quantitatively, if not qualitatively, so very different, that one powerful sensation must necessarily exclude fainter sensation; of a like order. Normally, vivid sensations of a particular order do tend to exclude with more or less completeness fainter like sensations. But the animal, in the circumstances in which it is placed, is as Mr. Wallace shows, in an abnormal condition. Its attention is concentrated on the unfamiliar succession of smells it is encountering, and under such a stimulus thes ordinarily fainter sensations may not unreasonably be supposed to become unwontedly vivid, and capable of powerfully affecting the animal's conscionsness, despite the resistance of what under common circumstances would prove an effectual obstacle to their conscious presentation. A complete experimentum crucis would require that the animal shoul, during the whole journey, be entirely smell-muffled, and Mr. Bennett's expedient could not, I think, be relied upon to produce this effect.

Camberwell, March 3

W. H. BREWER

\section{External Perception in Dogs}

THE following somewbat remarkable instance of a dog finding its way back was told me by the owner, who lived 20 or 25 miles up (and on the left bank of) the river Canumá, in Brazil ; a small niver just east of the river Madeira. He took the dog by boat down the river Canumá and up the Madeira to Borba, a small town on the right bank of the latter river; a distance of 70 or 80 miles round; and left the dog the re. The dog ran away from Borba and made its way back to its former home on the river Canumá. More exactly, it was making its way back, for my informant being out in the wood some little way inland, and S.W. of his cottage, fell in with it. It was in bad condition, having been some weeks-the exact time could not be ascertained-in working its way back through the forest, and of course had lived by hunting. I cannot give with ariy exactness the distance overland from Borba : perhaps it is less than 25 miles; and in this respect the return is not remarkable. It seems to me that the dog during its journey by water must have had a constant perception of the bearing of its old home; and on the other hand that it made its way back not by any blind instinct but by trial and error and by recognition of the character of the forest.

F. R. G. S.

\section{Sight in Dogs}

I THINK Mr. Kingsley rather underrates the exercise of the organs of vision by the dog when, in comparing it with the horse, he writes, " "The dog, who has smelt everything, but looked at very little." Now it is true that the dog does not look about him when on his travels, in the popular sense, by turning his head about, but close observation shows the eyeball in constant movement, taking in everything in front and on both sides, although, to all appearance, with his head close to the ground, his whole attention is concentrated on the reception of external impressions through his nose. This is particularly noticeable in the terrier, which, on meeting you, however intently he may seem to be engaged in smelling, gives a quick glance at your face without moving his head, or apparentiy lessening the atiention he is paying to something else with his nose. Note, aiso, how quickly a dog going down wind sees another a long distance off.

The horse not only sees and smells acutely but also frequently touches any object with his upper lip.

In reference to the quotation from "Boswell's Life of John. son," given by Mr. Nicoll, I may mention that it is well know $n$ to huntsmen that horses are very prone to kick if led near the hounds when a fox is being broken up, the explanation always given being that it is the smell of blood which irritates them.

Faringdon, March 9 J. Hopkins IVALTERS

\section{Selenium}

VITREOUS selenium may be considered a non-condictor of electricity. $\bar{I}$ : is only when in a crystalline condition that it be comes a conductor.

A bar now in my possession, $2.25 \times \cdot 5 \times \cdot 05$ inches, tested with an electromotive force of $\frac{1}{30}$ th of a Daniell's cell, gives a deflection of 140 divisions on the scale of an ordinary astatic mirror galvanometer. The same deflection produced under the same conditions through a known resistance, shows the resistance of the selenium to be 360,000 ohms. By the well-known Bridge system the resistance of the same plate of selenium is 359,500 ohms, the two different tests thus confirming each other.

I have to leave this evening for Valentia to report on the electrical condition of the Anglo-American Company's cab'e, or would write you more fully on the effect of light on the conductibility of selenium.

If selenium be expesed to the direct rays of the sun, it £radually becomes crystalline. May not the explanation of the phenomenon be found in this fact?

All the bars I have experimented upon have been supplied by Mr. H. Bassett, No. 2I5, Hampstead Road.

Wharf Road, City Road, March II 